М. О. Дудніков

канд. філол. наук, доцент

\title{
ЛІТЕРАТУРОЗНАВСТВО ПРО СТАНОВЛЕННЯ РОСІЙСЬКОГО ІСТОРИЧНОГО РОМАНУ (ДО ХХ СТ.)
}

У статті на матеріалі російської літератури XIX століття проаналізовано етапи формування жанру історичного роману. Визначено основні напрямки цього жанру: дидактичний (М. Загоскін, Ф. Булгарін, Р. Зотов), романтичний (М. Польовий, І. Лажечников) та реалістичний (О. Пушкін, М. Гоголь).

Виникнення та розвиток історичного роману припадає на 30 -ті роки XIX століття. Цей літературний жанр формувався в період руйнації феодального устрою та розвитку капіталістичних відносин. Імпульсом до розвитку народної національно-історичної свідомості стали події 1812-1825 років, які оголили проблеми національної культури та своєрідності народного характеру. За літературне джерело російського історичного роману при- 
йнято вважати повісті М. М. Карамзіна на історичну тему «Марфа Посадниця» та «Наталя, боярська донька», при цьому історизм його творів мав дидактичний характер, тобто історія розглядалася крізь призму моральних настанов.

Зафіксовано кілька найперших спроб створення історичних романів: у 1816 році М. С. Лунін пише історію Лжедимитрія (перша частина була надрукована французькою мовою, але до нашого часу не збереглася). У 1817 році вийшла окрема частина роману Ф. М. Глінки «Зиновій Богдан Хмельницький, або Визволена Малоросія». Окремим виданням у двох частинах роман вийшов 1819 року. Головний герой $є$ носієм патріотичних ідей, борцем за незалежність рідної землі. Через образ Богдана Хмельницького автор роману висловлює свої думки, а не розкриває, на жаль, багатогранний характер військового та політичного діяча. Народні маси, що перебувають під польським гнітом, у романі не представлені. Історичні події зображуються в річищі романтичної традиції: з'являється герой, якого підтримують небесні сили, тисячі людей підкоряються йому. Саме про такі стосунки Богдана Хмельницького 3 українським народом пише Ф. Глінка. Стилістична та образна система роману відірвана від конкретної історичної дійсності, також помітний вплив традицій класицизму та карамзінської прози.

Історична тема мала художню розробку в романтичних повістях О. О. Бестужева-Марлінського в 20-ті роки. О. С. Пушкін убачав у його повістях романні елементи, тому й радив писати романи. Бестужев вивчав питання про використання давніх мов, щоб детальніше відобразити історичне минуле, тобто торкався проблеми історичної стилізації.

Значну роль у розвитку реалістичної тенденції в історичній прозі відіграв декабрист О. О. Корнілович. О. С. Пушкін, коли працював над «Арапом Петра Великого», звертався до його історичного нарису про епоху Петра I. О. О. Корнілович не поділяв думки деяких істориків, що слава правителів реалізується тільки у військових перемогах. Необхідно звертати увагу на їх внутрішне життя та здібності до господарювання. У 1832 році Корнілович напише твір «Андрій Безіменний», пов'язаний 3 петровською епохою. Ім'я автора не вказане, але $\epsilon$ підзаголовок «Старовинна повість». Дворянина-патріота Андрія Безіменного цар захистив від переслідування слуг деспотичного Меншикова. Письменник-декабрист плекає надію на появу гуманного монарха, здатного відстояти права приниженої людини. I незважаючи на те, що автор правдиво зображує побут та звичаї петровського часу, характери не отримали певного розвитку, вони схематичні й не адаптовані до петровської епохи.

Паралельно з Росією історичний роман зародився й у Західній Європі. Світову популярність отримали романи Вальтера Скотта, які започаткували розвиток реалізму в історичному жанрі. Письменник зміг відобразити глобальні історичні події в історії країни, їх вплив на долі окремих людей. 
Англійський романіст широко зображує побут, національний колорит та реальні обставини життя своїх героїв. Він використовує археологічні та етнографічні деталі, що характеризують матеріальну й духовну культуру епохи. У романах В. Скотта особливе місце займає діалог, який розкриває характери численних персонажів. Характерною особливістю композиції романів В. Скотта $€$ те, що в центрі оповідання знаходяться видумані герої, a історичні діячі відіграють епізодичну роль і займають другорядне місце в структурі сюжету. Історичні романи В. Скотта торкалися нагальних сучасних проблем. Він глибоко розумів історичне життя, відчував шляхи історичного розвитку, був оригінальним мислителем. Основна тематика англійського письменника стосувалася нації, політичної концепції націй, буржуазних революцій. В. Скотт впливав на розвиток історичної науки, пропонував нові засоби розуміння людської історії. Під його впливом написано твори французьких учених Т’єррі «Історія завоювання Англії норманами» і Гізо «Історія революції в Англії». В історичних романах В. Скотта $\epsilon$ місце не лише історичним подіям, а й повсякденності. До того ж усі його історико-літературні спостереження щодо зображення звичаїв, епохи та ін. завжди пов'язані з сьогоденням.

В одній із журнальних статей про роман М. О. Польового «Клятва при Гробі Господньому» О. О. Бестужев-Марлінський писав: «Вальтер Скотт... відтворив історичний роман, який став потребою всього читаючого світу, від стін Москви до Вашингтону, від кабінету вельможі до прилавка дрібного гендляра» $[5,594]$.

У 30-ті роки XIX століття в російській літературі з'являється велика кількість історичних романів. Вагому роль у розвитку жанру відіграли «Юрій Милославський» (1829) та «Рославлєв» (1831) М.М. Загоскіна, «Дмитро Самозванець»(1830) Ф. В. Булгаріна, «Клятва при Гробі Господньому» (1832) М. О. Польового, «Останній Новік, або Завоювання Ліфляндії при царюванні Петра Великого», що виходили частинами у 18311833 роках, «Крижаний дім» (1835) і «Бусурман» (1838) I.I. Лажечникова. У 1835 році виходить у збірці «Миргород» повість М. В. Гоголя «Тарас Бульба», а в 1836 році - «Капітанська дочка» О. С. Пушкіна. Ці твори свідчили про факт становлення російського історичного роману.

Перший історичний роман М. Загоскіна «Юрій Милославський, або Росіяни у 1612 році» мав велику популярність. Письменник показав сцени старовинного російського життя, колоритно вималював характери Кирші, Олексія Бурнаша, Федьки Хом'яка тощо. Патріотичні почуття в романі розкриваються в контексті загальнонаціональної справи: згуртованість народних мас перед загрозою польського завоювання Москви. М. Загоскін торкнувся внутрішніх та соціальних стосунків у Росії, розкрив патріархальні відносини між боярами та кріпосним селянством. Письменник уважав, що прагнення до свободи та непокори непритаманне народу, воно занесене розбійниками та запорізькими козаками. М. Загоскін підтримував думку, 
що народ віддавна згуртований навколо царського престолу і православної віри. Інколи М. Загоскін не відтворював художньо історичні події, а сам про них розповідав, що приглушувало відчуття об'єктивності в підході до історичного факту, додавало роману дидактичного відтінку. Такий дидактизм нагадує історичну прозу М. Карамзіна, коли підноситься перемога позитивних героїв та поразка негативних персонажів. В. Бєлінський з приводу роману М. Загоскіна справедливо вказував: «Усі обличчя роману здійснення особистих понять автора; всі вони відчувають його почуттями, розуміють його розумом» $[3,36]$. Незважаючи на недоліки, роман «Юрій Милославський» $є$ етапним у російській прозі того часу, причому він написаний до творів О. Пушкіна і М. Гоголя.

М. Загоскін пише другий роман «Рославлєв, або Росіяни у 1812 році». Очевидним $є$ питання про зміни, що відбулися за два століття у свідомості людей стосовно ідеалів та патріотичних почуттів. Припускаючи логічність такого питання, М. Загоскін дає на нього відповідь у передмові до нового роману, підкреслюючи зовнішні зміни нації, але вірність престолу, віра предків, любов до рідної землі залишаються, на його думку, незмінними. У романі правдиво відображені епізоди війни, партизанського руху, картини провінційного побуту. До речі, автор був учасником війни 1812 року. Як і в попередньому творі М. Загоскін пише про єдність народу навколо царя та православної віри. Про події війни 1812 року ми дізнаємося з розмов героїв роману та коротких міркувань і довідок автора. У тексті багато моральних роздумів та сентиментальних відступів, але чомусь навіть причини розв'язання війни в романі не пояснено.

Подальші романи М. Загоскіна «Аскольдова могила», «Бринський ліс» відбивали події епохи Київської Русі, Петра I та Катерини II, але вони не внесли нічого нового в розвиток російського історичного роману. Про твори написані після «Рославлєва», В. Белінський писав: «... романи Загоскіна були один слабший від одного. У них він упадав у якусь дивну, псевдопатріотичну пропаганду та політику і почав з особливою любовію живописати розбиті носи та скигління відомого роду героїв, у яких він вбачає гідних представників суто російської моралі і з особистим пафосом прославляти любов до солених огірків та кислої капусти» $[4,55-56]$. Критика відмовлялася серйозно сприймати романи М. Загоскіна.

У цей самий час виходять історичні романи Ф. Булгаріна: «Дмитро Самозванець» (1830), «Петро Іванович Вижигін. Моралістичний історичний роман XIX століття» (1831) і «Мазепа» (1833-1834). Ф. Булгарін цікавиться петровською епохою, як і М. Загоскін, О. Пушкін, І. Лажечніков. Моральна мета романів письменника полягала в тому, щоб довести, що держава може бути щасливою в разі самовідданого служіння громадян вітчизні та святій вірі, а сила держави залежить від єднання царя з народом. Цю думку підтримував і М. Загоскін, але Ф. Булгаріна, на відміну від останнього, селянство взагалі не цікавить. Народне середовище, на думку 
Ф. Булгаріна, складають міщани, купці, представники церкви та службовці. Негативне ставлення письменника до народних заворушень не дає йому можливості відкрити істинні соціально-політичні протиріччя Смутного часу, i в художньому плані автор облагороджує історичне минуле, він уважає недоречним відтворювати в тексті грубість простонародного наріччя. Булгарінський роман «Петро Іванович Вижигін» розкриває воєнні події 1812 року. Автором перемоги над французами письменник вважає самодержавство. Історичні фігури в романах Булгаріна є носіями нав'язаних їм письменником морально-політичних ідей. Він переносить до жанру історичного роману елементи авантюрно-шахрайського роману - пригоди та шахрайства, - переплітаючи їх з подіями Вітчизняної війни 1812 року.

Тоді ж вийшли у світ історичні романи М.I. Воскресенського, Р. М. Зотова «Леонід, або Деякі риси із життя Наполеона» (1832), «Таємничий чинець, або Деякі риси із життя Петра I» (1834), але літературна критика дала їм низьку оцінку.

Особливою популярністю користувалися романи К. П. Масальского «Стрільці» (1832), «Регентство Бірона» (1834).

3'явилася серія романів про епоху І. Грозного: «Гаральд і Єлісавета, або Епоха Іоанна Грозного» (1831) В. А. Ертеля, анонімний «Малюта Скуратов, або Тринадцять років царювання царя Іоанна Васильовича Грозного» (1833), «Срмак, або Покорення Сибіру» (1834) П. П. Свіньїна. Історія і вимисел у цих творах погано поєднані, а історичні факти викривлено.

Розмову про реалізм в історичному романі першим повів О. С. Пушкін. Основну проблему він убачав у взаємодії історії та сучасності. Враховуючи вплив французького романтизму на розвиток російського історичного роману, О. Пушкін указував на недоліки історичного жанру у французьких письменників-романтиків. Він уважав неприпустимим приписувати людям минулого думки і почуття сучасної людини, оскільки подібний підхід до історичного матеріалу викривлює історію. О. Пушкін критикував реакційно-дидактичний напрям у російському історичному романі: «Що може бути моральніше за твори пана Булгаріна? Із них ми чітко дізнаємось: як погано брехати, красти, пиячити, грати в карти і тому подібне. Пан Булгарін карає персонажів різними химерними іменами: вбивця названий у нього Ножевим, хабарник Хабаріним, дурень Глаздуріним. Історична точність одна не дозволила йому назвати Бориса Годунова Хлопухіним, Дмитра Самозванця Каторжніковим, а Марину Мнішек княжною Шлюхіною» $[6,207]$. О. Пушкін був незадоволений і романом М. Загоскіна «Рославлєв, або Росіяни у 1812 році», тому пропонував свій варіант «Рославлєва». Це був другий роман О. Пушкіна на історичну тему після «Арапа Петра Великого». У «Рославлєві» М. Загоскіна народ показаний як пасивна сила, у пушкінському «Рославлєві» народ - міцна та загрозлива сила.

О. Пушкін, розкриваючи нові шляхи російської літератури, підтримував прояви реалізму в творах історичного жанру. Саме тому О. Пушкін да- 
вав високу оцінку першому роману М. Загоскіна «Юрій Милославський», історичній трагедії М. Погодіна «Марфа Посадниця». Пізніше позитивні відгуки О. Пушкіна отримають романи I.I. Лажечникова «Останній Новік» та «Крижаний дім». Високу оцінку отримає гоголівський «Тарас Бульба».

Романтична критика до правдивого зображення внутрішнього світу людини додавала таке поняття, як народність у зображенні історичного минулого, уміння передати дух нації, утілити національний характер народу, розкрити своєрідність його побуту. Про народність та історизм можна говорити в тих творах історичного жанру, де враховується місцевий колорит при зображенні побуту та звичаїв. Наприклад, М. Польовий, щоб виконати вимоги щодо поняття народності, у своєму романі «Клятва при Гробі Господньому» використовує сюжети з народними піснями та побутовими й церковними обрядами.

Великий успіх мав історичний роман О. Ф. Вельтмана «Кощій Безсмертний». Билини старого часу» (1833). Автор зробив вдалу спробу відтворення російської старовини. У «Кощії Безсмертному», як і в іншому романі про часи давнього Києва та Новгорода «Святославич, ворожий вихованець. Диво часу Червоного Сонця Володимира» (1835), Вельтман допомагає відчути дух епохи, зображує яскраві картини Давньої Русі, відтворюючи мову та синтаксис XII-XIV століть. Історичні романи М. О. Польового і О. Ф. Вельтмана являли собою обробку російської старовини з використанням фантастичних елементів.

У творчості I.I. Лажечникова історична тема зазнала подальшого розвитку. Письменник ретельно вивчав історичні документи, мемуари, навіть місцевість, де відбувалися події. Перший роман I.I. Лажечникова «Останній Новак» (1831-1833) присвячений прогресивним реформам Петра I, його турботам про розвиток освіти та культури. Головний герой роману, Новик, iз різних причин був вимушений жити за межами батьківщини. Одна 3 причин - конфлікт із петровською владою. Із-за кордону Новик стежить за станом справ у Росії, визнає прогресивну діяльність Петра. Коли між Росією та Швецією розпочалася війна, Новик таємно почав надавати допомогу російській армії: він зміг увійти в довіру до командуючого шведськими військами Шліппенбаха, а потім передавав військову секретну інформацію командуючому російської армії в Ліфляндії Шеремет'єву. герой таємно повертається на батьківщину, йому вибачають усі провини, але брати участь у розбудові своєї держави не вистачає сил. Наш герой знаходить собі притулок у монастирі. На жаль, I.I. Лажечников не зміг показати головні соціальні протиріччя петровської епохи, тому що як цар, так і його оточення представлені ідеалізовано.

Другий роман I.I. Лажечникова «Крижаний дім» (1835) присвячений жорстокому періоду російської історії - царюванню Анни Іоанівни. Автор показує ганебне становище Росії, руйнування країни, яка ще недавно прагнула до прогресу та економічних змін. Крім цариці Анни, показаний образ 
підступного Бірона, а також Волинського, що веде з ним політичну боротьбу. У третьому романі «Бусурман» (1838) виведено образ лікаряіноземця Антона Еренштейна відтворений романтичним уявленням письменника. Лікар, який потрапив до Москви в XV столітті, здивований жорстокими звичаями країни. Головний герой гине як жертва боярської обмеженості та жорстокості. Ті ліки, які він виписав татарському царевичу, замінили на отруту, звинувативши «бусурмана» в навмисному вбивстві. Незважаючи на недоліки художнього втілення цього образу, він був глибоко новаторським. Утративши дворянські привілеї, лікар визнає свою людську гідність не в походженні, а в знаннях та культурі.

У 1831-1832 роках починає писати історичний роман із часів пугачовщини М. Ю. Лермонтов. Його роман «Вадим» залишився незавершеним. Незважаючи на те, що твір Лермонтова перетинається з історичною прозою Лажечникова та Марлінського, письменник глибше досліджує конфлікт народних мас. У цьому питанні він наближається до поглядів О. Радищева. У «Вадимі» помітне пробудження соціальної свідомості кріпаків, які іронічно ставляться до пана. При цьому слід зазначити, що М. Лермонтов по-різному оцінював ідею народної помсти. 3 одного боку, автор роману визнає зародження народного незадоволення кріпацькою системою, а з іншого - боїться народного стихійного бунту. М. Лермонтов, на відміну від О. Пушкіна, не підтримував думку про неминучість історичного прогресу як фактора свободи.

У процесі творчих пошуків прийшов до реалізму в зображенні історичного минулого і М. Гоголь. Його романи «Страшна помста» та «Гетьман» були підготовчим етапом до «Тараса Бульби».

В історичному романі першої половини 30 -х років XIX століття сформувалися три напрямки. Перший визначається як дидактичний (його представники: М. Загоскін, Ф. Булгарін, К. Масальський, Р. Зотов). Витоки цього методу спостерігаються в історичній прозі М. Карамзіна. В. Бєлінський про дидактичний метод писав: «Усяка думка, яка з'являється поза художнім та літературним інтересом, самостійно й окремо від форми, приймаючи $\dddot{11}$ цілком випадково, не як необхідна умова свого існування, але як засіб висловитися, - така думка неминуче стає мертвою, а романи, породжені нею, дидактичними...» [2, 291].

Другий напрямок - романтичний (його представники: М. Польовий, I. Лажечников). Передбачали цей напрямок повісті Бестужева 20 -х років. Історичний роман М. Польового знаходився під впливом французького романтизму. І. Лажечников був прибічником реалістичного методу дослідження історичних подій, знаходився під впливом В. Скотта.

Підгрунтям романів цих двох напрямків $є$ ідеалістичне розуміння історії. Так, наприклад, для М. Загоскіна живим імпульсом історії $\epsilon$ моральні та релігійні ідеї. І. Лажечников велике значення приділяє звичаям, а також освіті як засобу впливу на долі та характери людей. Романтичному напря- 
мку в історичному романі характерне перебільшення ролі особистості в історії. Видатний історичний діяч завжди в зображенні письменників виявляє себе як виключна особистість, вільна у своїх вчинках. Часто історична постать ставала рупором ідей автора.

Третій напрямок - реалістичний. Його засновниками визнані О. С. Пушкін та М. В. Гоголь. Так, у повісті О. Пушкіна «Капітанська дочка» висловлено не тільки роздуми про історичне минуле, а й більшою мірою ставлення автора до сучасних політичних та соціальних проблем, актуальних російському життю $30-\mathrm{x}$ років. Зображуючи повстання О. Пугачова, письменник показав кріпосницькі стосунки між селянами та дворянством, між козацтвом та державою.

О. Пушкін вплинув і на реалізм М. Гоголя. Свою епопею останній назвав повістю тому, що хотів підкреслити її епічний і реалістичний характер, що відрізняв «Тараса Бульбу» від сучасних письменнику історичних романів школи романтизму.

Велику роль у розвитку історичного роману відіграли реалістичні теоpiї в критиці В. Бєлінського, який твердив, що вся подальша діяльність прогресивної думки повинна спиратися на історію, зростати на історичному грунті. Від вірувань та ідеалів, не підкріплених історією, людство перейшло до нової епохи, перейнятої історичною свідомістю. Віра в абстрактний розум, характерна для XVIII століття, а також епоха романтичного суб'єктивізму змінюються періодом об'єктивного пізнання історії, іiі закономірностей. На думку Бєлінського, сучасна форма історичного роману породжена тим, що в самій дійсності події перетинаються 3 долею окремої людини, і саме окрема людина бере участь в історичних подіях. Заслугою В. Скотта Бєлінський вважав той факт, що англійський письменник першим у своїх романах вирішив проблему поєднання історичного життя 3 приватним.

В історичному романі В. Бєлінський виділив особливий підвид, який назвав «поетичною біографією» $[1,194]$. У наш час цей підвид має назву історико-біографічного роману. Особливу рису цього підвиду Бєлінський вбачав у тому, що автор, користуючись фактом із життя історичного діяча, «описує цю подію, як вона йому уявлялася» $[1,194]$. Головне призначення історичного роману нового часу критик вбачав у розкритті національноісторичного обличчя народу, його національного характеру. Історичний роман Бєлінський сприймав як засіб пізнання минулого, тому він закликає пройнятися духом часу, зрозуміти історичні форми національного життя, постаратися стати сучасником подій, пережити їх, зрозуміти те, що обрав предметом свого зображення, а потім творчо відтворити його. «Поет не може і не повинен бути рабом історії, як він не може і не повинен бути рабом дійсного життя, тому що в тому і іншому випадку, він був би копіїстом, а не творцем. Вітаємо поета, якщо герой його роману або драми цілком схожий з героєм історії, якого він виводить у своєму творінні; але це 
може бути тільки в тому випадку, коли поет угадає історичне обличчя, коли його фантазія вільно зійдеться з дійсністю» $[1,132]$.

У 40-х роках з'явилося декілька історичних романів, які не відрізнялися самобутністю та новаторством. Так, історико-побутовий роман «Кузьма Петрович Мірошев» (1842) має відношення до часів правління Катерини II, а в романі «Бринський ліс» (1846) з епохи Петра I М. Загоскін повторюється в ідейно-тематичному плані, проводить все ті ж ідеї офіційної народності. У 1841 році Н. В. Кукольник написав роман «Евеліна де Вальєроль», події якого відбуваються у Франції за часів кардинала Рішельє. На концепцію цього твору вплинув роман А. де Віньї «Сен-Мар». В. Бєлінський дає досить високу оцінку історичним повістям Н. В. Кукольника та його історико-побутовому роману «Два Івана, два Степанича, два Костилькова» (1844), зміст яких має відношення до епохи Петра I. 31824 по 1843 роки писався роман Б. М. Федорова «Князь Курбський».

Наприкінці 40-х років XIX століття спостерігається занепад жанру історичного роману, і тільки в 60-ті роки з'являється в світовій літературі класичний зразок історичного роману Л. М. Толстого «Війна і мир».

У 70-90-х роках досить популярними були історичні романи Г. П. Данилевського та Д. Л. Мордовцева. Кращим романом Г. П. Данилевського вважається «Спалена Москва» (1874). Автор висвітлює події Вітчизняної війни 1812 року. Інколи історія в Г. П. Данилевського пов'язана 3 особистістю та іï приватними інтересами («Мирович» (1875)). У його романі «Княжна Тараканова» інтрига будується на інтимному житті монархів та їх оточенні.

В основу історичного роману Д. Л. Мордовцева покладено важливі історичні події. Так, у романі «Господін Великий Новгород» (1882) письменник пише про події, що відбувалися в останні роки незалежності Новгороду під час його боротьби проти політики Москви. У романі «Ідеалісти і реалісти» (1878) Д. Л. Мордовцев негативно втілює діяльність Петра I та ідеалізує супротивників його справи.

Підсумком розвитку історичного роману XIX століття стане трилогія Д. Мережковського «Христос і Антихрист», яка складається з книг: «Знедолений. Смерть богів» («Юліан Відступник», 1886), «Воскреслі боги» («Леонардо да Вінчі», 1901), «Антихрист» («Петро і Олексій», 1905). Автор висловив своє уявлення про історію та майбутній розвиток людства. «У світовому житті, - твердив Мережковський, - завжди існувала та існує полярність, у ній борються дві правди - небесна і земна, дух і плоть, Христос і Антихрист. Перша проявляється в прагненні духу до самозречення $\mathrm{i}$ злиття з Богом, друга - в прагненні людської особистості до самоствердження свого «я», панування індивідуальної волі. В історії ці два потоки в передчутті майбутньої їх гармонії роз'єднуються, але дух постійно прагне до того вищого злиття, яке, на думку письменника, увінчає історичну завершеність» $[7,39]$. 
Історичні романи М. Загоскіна «Юрій Милославський» (1829), Ф. Булгаріна «Дмитро Самозванець»(1830), М. Польового «Клятва при Гробі Господньому» (1832), І. Лажечникова «Крижаний дім» (1835), «Бусурман» (1838), повісті М. Гоголя «Тарас Бульба» (1835) та О. Пушкіна «Капітанська дочка» визнані літературознавцями як твори, що надали певну жанрову стабільність російському історичному роману, а автори цих творів уважаються знаковими постатями російської літератури XIX століття, особливо в плані історичної прози. Вони витворювали не лише історію подій, але й історію культури. Російська історична романістика, яка веде початок від доби романтизму, розвивалася в тісному зв'язку загальнонаціональних історичних та соціальних процесів. При цьому формування історичного роману відбувалося методом спроб та помилок, накопичувався арсенал художніх засобів, який надавав йому жанрової різноманітності, а стабільність полягала в тематиці та історичній достовірності.

\section{Список використаної літератури}

1. Белинский В. Г. Полное собрание сочинений. - М.: Изд-во АН СССР, 1953. T. 2. $-766 \mathrm{c}$.

2. Белинский В. Г. Полное собрание сочинений. - М.: Изд-во АН СССР, 1953. Т. 3. $-682 \mathrm{c}$.

3. Белинский В. Г. Полное собрание сочинений. - М.: Изд-во АН СССР, 1955. Т. 6. -797 с.

4. Белинский В. Г. Полное собрание сочинений. - М.: Изд-во АН СССР, 1955. Т. $8 .-728 \mathrm{c}$.

5. Бестужев-Марлинский А. А. Сочинения. - М.: Гослитиздат, 1958. - Т. 2. $670 \mathrm{c}$.

6. Пушкин А. С. Полное собрание сочинений. - М.: Изд-во АН СССР, 1949. T. $10 .-474 \mathrm{c}$.

7. Соколов А. Г. Судьбы русской литературной эмиграции 1920-х годов. - М.: Изд-во МГУ, 1991. - 184 с.

\section{Summary}

Taking into consideration the data fixed in the literary field, the article highlights the main stages of developing the Russian historic novel in the XIX-th century. It deals with the historic novels by Zagoskin, Bulgarin, Polevoy, Lashechnikov, Gogol, Pushkin, Tolstoy. All these novels prove the fact of the genesis of the genre in question in Russia. 